The Intertidal Marine Lichen Formed by the Pyrenomycete Fungus Verrucaria tavaresiae (Ascomycotina) and the Brown Alga Petroderma maculiforme (Phaeophyceae): Thallus Organization and Symbiont Interaction Author(s): William B. Sanders, Richard L. Moe, Carmen Ascaso

Source: American Journal of Botany, Vol. 91, No. 4 (Apr., 2004), pp. 511-522

Published by: Botanical Society of America

Stable URL: http://www.jstor.org/stable/4123679

Accessed: $25 / 01 / 2011$ 03:36

Your use of the JSTOR archive indicates your acceptance of JSTOR's Terms and Conditions of Use, available at http://www.jstor.org/page/info/about/policies/terms.jsp. JSTOR's Terms and Conditions of Use provides, in part, that unless you have obtained prior permission, you may not download an entire issue of a journal or multiple copies of articles, and you may use content in the JSTOR archive only for your personal, non-commercial use.

Please contact the publisher regarding any further use of this work. Publisher contact information may be obtained at http://www.jstor.org/action/showPublisher?publisherCode=botsam.

Each copy of any part of a JSTOR transmission must contain the same copyright notice that appears on the screen or printed page of such transmission.

JSTOR is a not-for-profit service that helps scholars, researchers, and students discover, use, and build upon a wide range of content in a trusted digital archive. We use information technology and tools to increase productivity and facilitate new forms of scholarship. For more information about JSTOR, please contact support@ jstor.org. 


\title{
THE INTERTIDAL MARINE LICHEN FORMED BY THE PYRENOMYCETE FUNGUS VERRUCARIA TAVARESIAE (ASCOMYCOTINA) AND THE BROWN ALGA Petroderma maculiforme (Phaeophyceae): THALLUS ORGANIZATION AND SYMBIONT INTERACTION ${ }^{1}$
}

\author{
William B. Sanders, ${ }^{2,3,4}$ Richard L. Moe, ${ }^{3}$ AND Carmen AsCaso ${ }^{2}$ \\ ${ }^{2}$ Centro de Ciencias Medioambientales, C.S.I.C., Calle Serrano 115 bis, 28006 Madrid, Spain; and \\ ${ }^{3}$ University Herbarium, University of California, Berkeley, California 94720-2465 USA
}

\begin{abstract}
The thallus formed by the marine pyrenomycete fungus Verrucaria tavaresiae and the phaeophycean alga Petroderma maculiforme was studied to elucidate the organization of the symbionts, determine the type of cellular contacts between them, and evaluate the status of the symbiosis as a lichen. Hand-sectioned and resin-embedded samples were examined with light and transmission electron microscopy. Within the uppermost portion of the cellular fungal tissue, separate algal filaments were arranged anticlinally. Protrusions of the fungal cell wall penetrated into adjacent algal walls but did not enter the cell lumen. A striking feature of these penetrations was the frequent separation of algal cell wall layers and insertion of fungal wall material between them. Algal filaments grew downward intrusively between fungal cells, often penetrating deeply into the fungal cell wall. Despite the exceptional nature of the phycobiont involved, the Verrucaria tavaresiae-Petroderma maculiforme symbiosis unequivocally fits the prevailing concept of a lichen. The distinctive interpenetrations observed between symbionts may be related to the integration of their different growth forms within a coherent tissue regularly subject to mechanical stresses. Periclinal cell divisions within and just below the algal layer may serve to replenish surface tissues lost to abrasion and herbivory.
\end{abstract}

Key words: haustoria; marine lichen; mycophycobiosis; Petroderma maculiforme; Phaeophyceae; phycobiont; pyrenomycetes; Verrucaria tavaresiae.

Nearly all known lichen fungi associate with green or bluegreen algal symbionts or both. The recently described intertidal marine ascomycete Verrucaria tavaresiae (Moe, 1997) is the only fungus reported to form a lichen association with a brown alga (Phaeophyceae). The phycobiont isolated from the symbiotic thallus was identified as Petroderma maculiforme (Wollny) Kuckuck (Wynne, 1969). This result was subsequently confirmed by morphological and molecular comparison of algal isolates with material cultured from type locality collections (Peters and Moe, 2001).

Free-living Petroderma maculiforme produces a small discoid thallus of appressed radial filaments, the cells of which give rise to a cushion of laterally coherent, erect filaments (Edelstein and McLachlan, 1969; Wilce et al., 1970). Although relatively simple compared to many other brown algae, this species would nonetheless be among the most structurally complex of algae known to enter into lichen symbioses. Most other lichen phycobionts are unicellular or short-filamentous microalgae (Tschermak-Woess, 1988).

On the other hand, there are a few apparently obligate symbioses between ascomycete fungi and complex macroalgae

' Manuscript received 14 August 2003; revision accepted 4 December 2003. W. B. S. gratefully acknowledges fellowship support provided by the Spanish Secretaría de Estado de Educación y Universidades. Financing was also obtained via Project BOS 2000-1121. Technical advice and assistance was provided by the staff of the Electron Microscopy Laboratory (University of California) in Berkeley and by Sara Lapole and Fernando Pinto (CCMACSIC) in Madrid. The manuscript benefited from critical review by Shirley Tucker and an anonymous referee.

This work is dedicated to Dr. Isabelle I. Tavares, Curator Emerita of fungi and lichens at the University Herbarium (Berkeley) and namesake of the species $V$. tavaresiae, on the occasion of her 82 nd birthday.

${ }^{4}$ E-mail: william@ccma.csic.es. that have generally not been treated as lichens. For example, the ubiquitous association of the fungus Mycophycias ascophylli with the phaeophycean rockweed Ascophyllum nodosum has been termed a mycophycobiosis rather than a lichen (Kohlmeyer and Kohlmeyer, 1972; Kohlmeyer and Volkmann-Kohlmeyer, 1998). The distinction was made on the grounds that the microscopic fungus in that association merely invades the tissues of the seaweed without engendering any morphological transformation or construction of a distinctive thallus.

Taking these different partnerships into account, Moe (1997) indicated that the Verrucaria tavaresiae-Petroderma maculiforme symbiosis should be considered a lichen. However, no structural study of this unique association has yet been published, despite repeated citation of the thesis in which it was first mentioned decades ago (Wynne, 1969). The neglect of these organisms is particularly surprising in view of their presence on the urbanized shores of cosmopolitan San Francisco Bay (California, USA). The present work investigates the organization of their symbiotic thallus and the types of cellular contacts between symbionts, providing evidence regarding the status of the association as a lichen.

\section{MATERIALS AND METHODS}

Known distribution of the symbionts-Free-living Petroderma maculifor$m e$ has been reported from coastal areas of the North Sea, the North Atlantic, California, Pacific northwestern North America, the Red Sea, and austral and antarctic territories (Wilce et al., 1970; Asensi et al., 1977). However, the symbiotic thallus it forms in association with the fungus Verrucaria tavaresiae is known only from maritime northern and central California, USA (Wynne, 1969; Moe, 1997; Tucker, 1999).

Light microscopy-Hand sections of Verrucaria tavaresiae were prepared from material collected from the middle-upper intertidal zone in San Francisco 

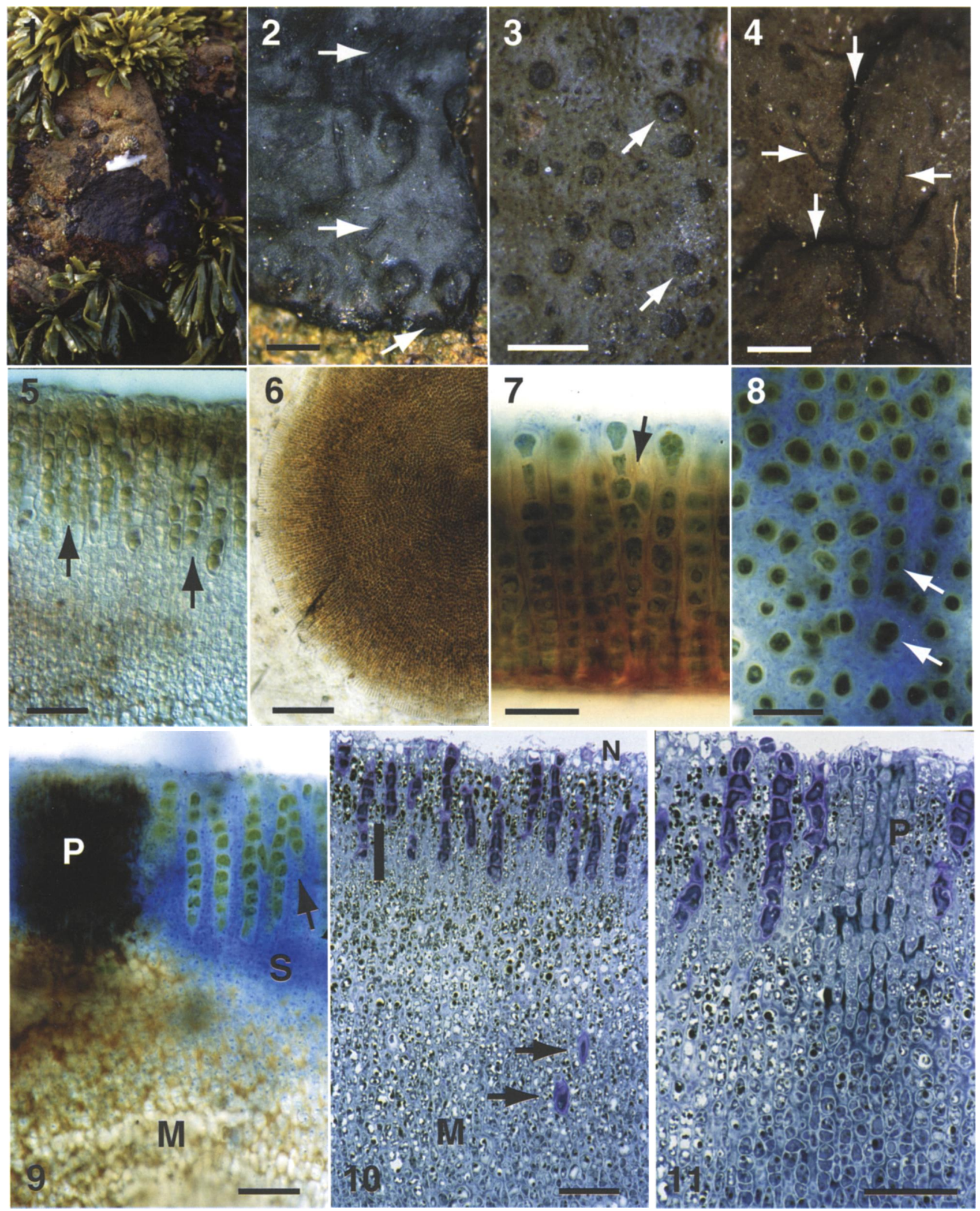

Figs. 1-11. Verrucaria tavaresiae and Petroderma maculiforme. Habit, dissecting microscope and light microscope images. Symbiotic thallus shown in all figures except 6 and 7, which depict free-living P. maculiforme. 1. Crustose symbiotic thallus of Verrucaria tavaresiae (immediately below white marker at center) among rockweeds Pelvetiopsis limitata Gardner (Fucales). On sandstone in intertidal zone of San Francisco Bay at Fort Mason, San Francisco, California, USA. Scale is approximately one-fourth actual size. 2. Moist symbiotic thallus. Horizontal arrows show radula marks left by a gastropod grazer. Oblique arrow indicates short prothallus visible as dark marginal band. Scale bar $=1 \mathrm{~mm}$. 3. Surface of thallus after moderate drying. Dark circles are embedded perithecia (arrows); many of the small, dark specks among perithecia correspond to pycnidia. Scale bar $=1 \mathrm{~mm}$. 4. Surface of thallus after moderate drying. 
Bay (Treasure Island and Fort Mason, San Francisco County) and on the Pacific coast at McClure's Beach (Marin County), California, USA. Thalli were growing on sandstone rock faces with a northern exposure. Voucher specimens are deposited at the University Herbarium, Berkeley (UC).

Electron microscopy-As lichen material has often proven difficult to process adequately for transmission electron microscopy (TEM), we used a microwave-assisted protocol for fixation and embedding, developed by the Electron Microscopy Laboratory of the University of California at Berkeley. Specimens collected at Fort Mason were kept moist with seawater and processed within $24 \mathrm{~h}$ at the EM Laboratory in Berkeley. The thallus was cut transversely into sections approximately $2 \times 1 \times 0.3 \mathrm{~mm}$. Material was fixed in glutaraldehyde diluted to $2 \%$ with seawater, postfixed with osmium tetroxide, dehydrated in acetone series, and embedded in Spurr's low-viscosity resin. Fixation, dehydration, and embedding were carried out under vacuum within a laboratory-adapted microwave oven (Ted Pella) provided with a watercooled specimen pedestal. A restriction temperature of $35^{\circ} \mathrm{C}$ (above which the microwave automatically shuts off) was employed. Ultrathin sections were prepared with an Ultracut E microtome (Reichert-Jung) and examined with a Leo 910 transmission electron microscope (Zeiss) at the Centro de Ciencias Medioambientales, C.S.I.C, in Madrid.

\section{RESULTS}

External appearance of the thallus - In the upper intertidal zone of San Francisco Bay, Verrucaria tavaresiae formed very dark, crustose thalli, often reaching several centimeters in diameter (Fig. 1). These rather undistinguished patches closely resembled co-occurring crustose algae, such as Mastocarpus (Petrocelis) and Hildenbrandia, or even splotches of tar, when wet (Fig. 2). As the thallus dried, the dark brown to blackish color changed to dark greyish tan. Against this somewhat lighter shade, the more darkly pigmented surface features of the thallus became increasingly visible. These included the borders of perithecial and pycnidial ostioles (Fig. 3), as well as black dots ("puncta") and band-shaped marks ("juga" or "striae"). Upon drying, the thallus surface cracked; these cracks often coincided with the darkly pigmented bands in the thallus surface (Fig. 4).

Light microscopic description of the vegetative thallus-A cross section of the symbiotic thallus revealed a densely packed cellular construction stratified into distinct layers, with little or no intercellular spaces visible (Figs. 5, 9-11). In the uppermost layer, anticlinally oriented (= perpendicular to surface) algal filaments were embedded within a tissue of more or less isodiametric fungal cells arranged mainly in anticlinal files. This zone will be referred to as the algal layer. In unstained sections of the symbiotic thallus (Fig. 5), the algal filaments were a golden brown color comparable to that of the free-living alga (Fig. 6). Free-living Petroderma produced a discoid thallus of horizontal, closely appressed, radial filaments (Fig. 6), the cells of which gave rise to laterally coherent, upwardly branching filaments that sometimes terminated in unilocular zooangia (Fig. 7). In the symbiotic condition, by contrast, the phycobiont was present as discrete, independent filaments separated from each other by surrounding fungal cells (Figs. 8, 9). The polarity of phycobiont filament branching was mainly downward into the fungal tissue (Fig. 9), and zooangia were never observed. The symbiotic thallus had no overlying cortex, although a thin epinecral layer of dead fungal and algal cells often accumulated at the upper surface (Figs. $10-11)$. Files of mycobiont cells adjacent to the algal filaments were continuous with similar tissue below the algal layer, here referred to as the subalgal layer. The fungal cytoplasm in these layers stained strongly with aniline (cotton) blue, especially in the lower portion of the algal layer and in the upper portion of the subalgal layer (Figs. 9, 14, 19). Occasionally, isolated phycobiont cells or short lengths of filaments appeared within the subalgal layer or even within the upper portion of the underlying medulla (Fig. 10). Beneath the subalgal layer, the medullary region comprised somewhat larger, more rounded, elongate or irregularly shaped fungal cells with little or no apparent organization into files. The cytoplasm of the medullary cells stained less densely with aniline blue than that of the fungal cells in the subalgal and algal layers above, and the cell walls were usually impregnated with a brown pigmentation (Fig. 9). In embedded sections, the cytoplasm and cell walls of the medullary cells stained strongly with toluidine blue (Figs. 10-11).

Brown pigmentation of the mycobiont cell walls also occurred as bands or points passing through the upper layers of the thallus. The markings corresponded to either upward intrusions of pigmented medullary tissue reaching to the surface or superficial sectors of pigmented tissue not apparently continuous with that of the medulla (Figs. 9, 14). The pigmented bands appeared to represent regions of reduced mechanical strength, as cracking of the upper portion of the thallus upon drying tended to occur in these pigmented zones (Figs. 1213). The cells of the pigmented medullary tissue continuing upward to the surface were cytologically distinct from adjacent files of mycobiont cells within the algal layer (Fig. 11).

Margins of the thallus-Along the perimeter of the symbiotic thallus, a narrow prothallus of fungal tissue (Fig. 2) adhered closely to the substrate and was difficult to dislodge

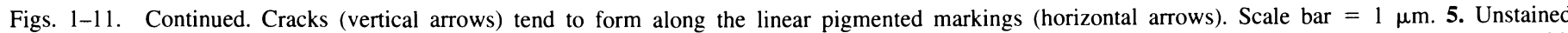

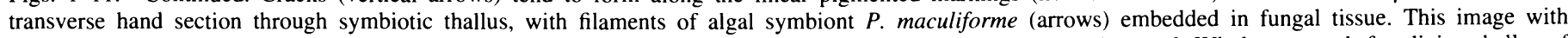

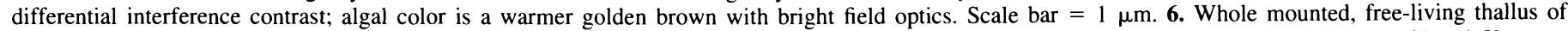

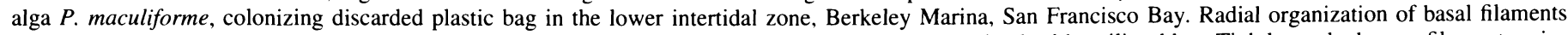

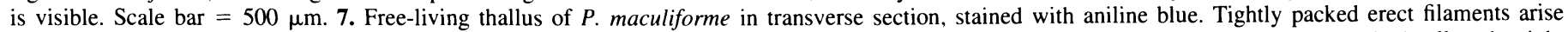

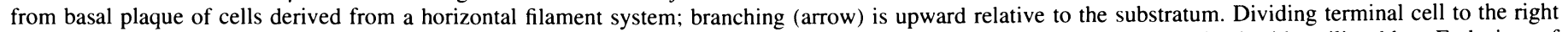

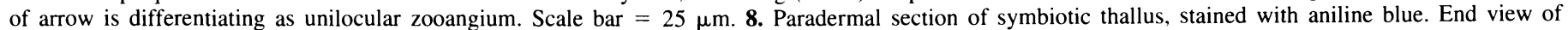

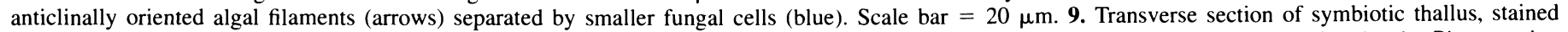

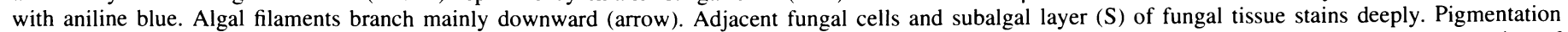

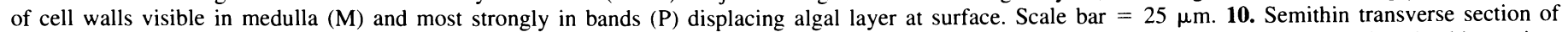

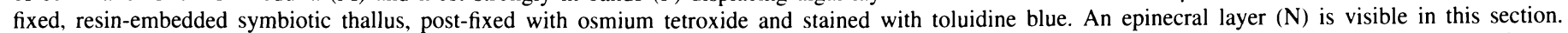

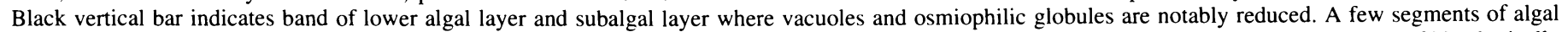

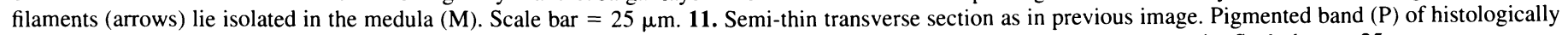
distinctive cells, continuous with medulla, displace algal cells near surface. Note that these pigmented cells are not necrotic. Scale bar $=25 \mu \mathrm{m}$. 


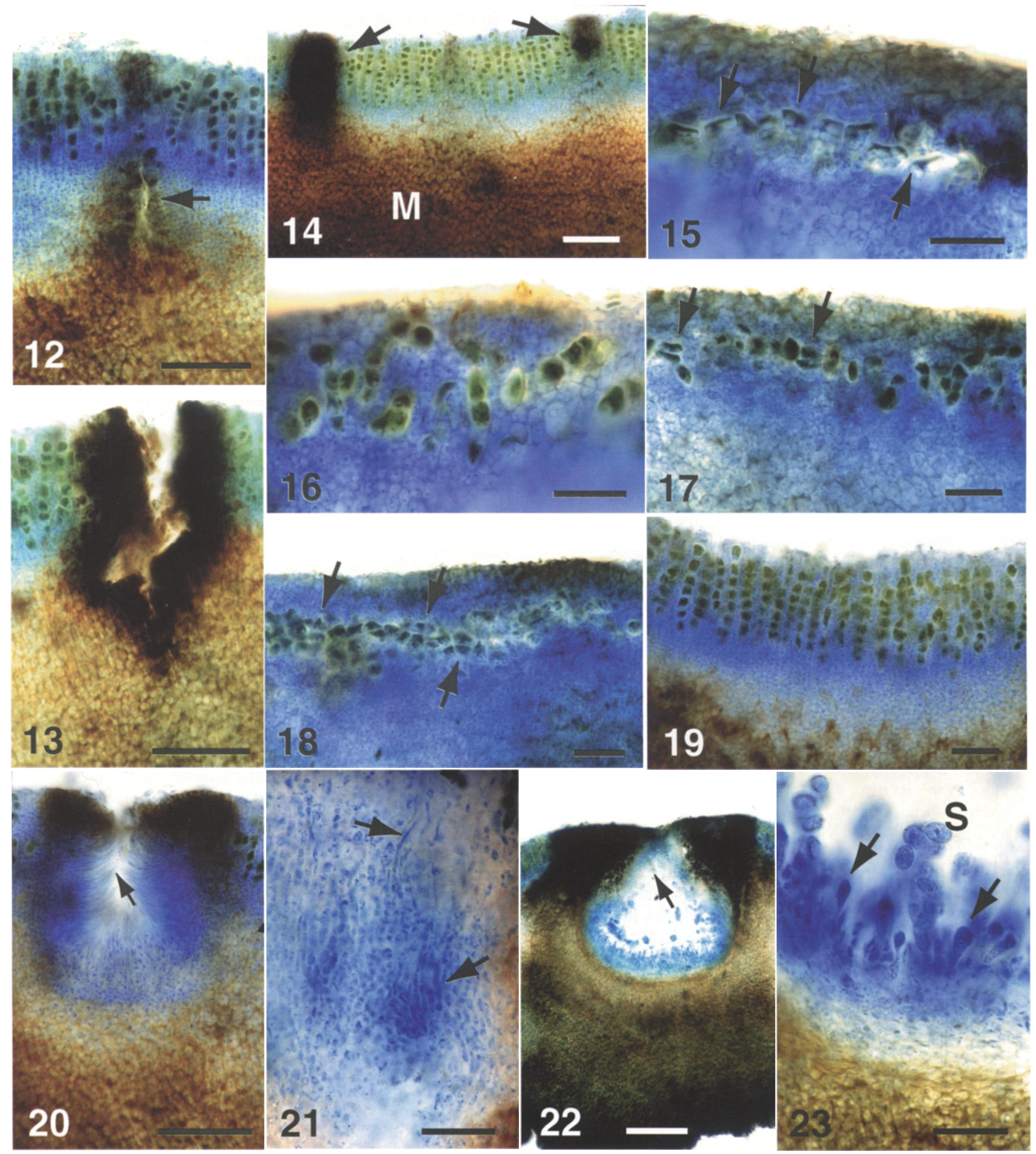

Figs. 12-23. Symbiotic thallus of Verrucaria tavaresiae-Petroderma maculiforme: light micrographs of transverse hand sections stained with aniline blue. 12. Fissure developing (arrow) within pigmented band. Scale bar $=50 \mu \mathrm{m}$. 13. Cracking of thallus along pigmented band. Scale bar $=50 \mu \mathrm{m}$. 14. Pigmented bands (arrows), continuous with medulla (M) at left, isolated in upper thallus at right. Scale bar $=50 \mu \mathrm{m}$. 15. Margin of thallus. Algal layer as a simple, periclinal filament system (arrows). Scale bar $=20 \mu \mathrm{m}$. 16. Adjacent to thallus margin. Algal layer disorganized, with filaments in various orientations. Scale $\mathrm{bar}=25 \mu \mathrm{m}$. 17. Adjacent to thallus margin. Primary horizontal filament system of alga with some periclinal cell divisions (arrows). Scale bar $=25 \mu \mathrm{m}$. 18 . Adjacent to thallus margin. Alga showing abundant periclinal divisions (arrows). Scale bar $=25 \mu \mathrm{m}$. 19. Submarginal region, $500-1000 \mu \mathrm{m}$ from thallus margin. Algal layer has assumed mature organization with separated filaments oriented mainly anticlinally. Scale bar $=50 \mu \mathrm{m}$. 20 . Pycnidium, bearing filiform conidia (arrow). Scale bar $=50 \mu \mathrm{m}$. 21. Primordium of ascoma, with densely staining ascogonial or ascogenous hyphae (arrows). Scale bar $=25 \mu \mathrm{m}$. 22 . Perithecium, with darkened involucrellum surrounding ostiole. Periphyses present at neck (arrow). Scale bar $=100 \mu \mathrm{m}$. 23. Hymenial layer, showing asci (arrows) and ascospores (S). Scale bar $=25 \mu \mathrm{m}$. 
intact for examination. Within the fungal tissue just proximal to the prothallus, the phycobiont was present as a single layer of algal filaments oriented parallel to the surface (Fig. 15). With increasing distance from the margin, the cells of the horizontal filament system became increasingly separated from each other. Some sections show filament growth becoming oblique and disorganized, then increasingly anticlinal in orientation (Fig. 16); others show periclinal divisions (= new crosswalls parallel to surface) giving rise to anticlinal files of algal cells (Figs. 17-18). About 500-1000 $\mu \mathrm{m}$ from the prothallic margin, the algal layer assumed its mature structure, with most algal filaments fully anticlinal and distinctly separated from each other by surrounding fungal cells (Fig. 19).

Reproductive structures of the mycobiont-Pycnidia developed at the thallus surface beneath a dense superficial deposit of pigmentation (Fig. 20). The pycnoconidia were filiform. Ascomatal primordia similarly developed below pigmented superficial cells. Cells of distinctive morphology, densely staining in lactophenol-cotton blue, were observed in the center of the primordia; these cells appeared to form part of an ascogonial complex (Fig. 21). A dense ring of dark pigmentation surrounded the ostiole of the mature perithecium. The inner surface of the perithecial neck was lined with periphyses (Fig. 22). The mature hymenium lacked interascal filaments. Asci were club-shaped; ascospores ovoid, simple, eight per ascus, 12-15 $\times 5-7 \mu \mathrm{m}$ (Fig. 23). Further details of reproductive characters are provided by Moe (1997).

Ultrastructure of fungal and algal symbionts-Intimate symbiont contact was evident throughout the algal layer, where fungal and algal walls were in continuous apposition (Fig. 24). The algal cell wall was more distinctly delimited, substantially more electron-dense, and had a definite layered structure. Algal filament crosswalls were traversed by plasmodesmata. The chloroplast often occupied much of the algal cell volume. They were frequently lobed, varying substantially in discernable shape and orientation. A large central pyrenoid was often conspicuous, with chloroplast lobes folded around it (Fig. 24). An invagination of the chloroplast membrane ramified throughout the pyrenoid, forming a network of branched tubules (Fig. 25; see also Asensi et al., 1977). Although chloroplast number could not be determined with certainty from nonserial sections, one chloroplast per cell seemed to be the most common condition. Sometimes, the presence of two separate chloroplasts per cell could be confirmed when the central pyrenoids of both were clearly visible (Fig. 27). Plastoglobuli were generally absent from the pyrenoid, but occurred in short rows or clusters within dilations of stroma between the lamellae (Fig. 25). Mitochondria were conspicuous and abundant in many of the algal cells (Fig. 24). Further details of Petroderma ultrastructure will be presented in a separate work comparing the lichenized and free-living states.

The relatively electron-transparent fungal cell walls often appeared gelatinized into a matrix of highly variable thickness, within which individual cell walls were not always readily distinguishable (Fig. 24). Fungal cell lumina in the algal and subalgal layers were approximately isodiametric to about twice taller than broad. The most notable feature of the fungal protoplasts was the system of overlapping vacuoles and the highly osmiophilic bodies frequently associated with them. These extremely electron-dense bodies usually occurred singly to a vac- uole; generally, several such vacuoles were present in each cell. The osmiophilic bodies were often quite large relative to cell volume (Fig. 24), although they appeared distinctly smaller in many cells showing recent division (Figs. 26, 28). Cell division was mainly periclinal (Fig. 26), but oblique to anticlinal divisions also occurred (Figs. 28-29). Septum development was often asymmetrical (Fig. 28).

Cells of the medulla tended to be more irregularly shaped or even hypha-like. The intercellular matrix material in this zone was electron-dense and readily disinguishable from the fungal cell wall proper (Figs. 30-32). Within many medullary cells, large, electron-dense, lipid-like globules, generally not associated with a vacuolar system, occupied a substantial portion of the protoplast volume (Fig. 30). Intrahyphal hyphae were common (Fig. 30), invasion occurring between adjacent cells of the same hypha (Fig. 31). Anastomoses between adjacent hyphae occurred frequently (Fig. 32).

Contacts and interactions between symbionts-Intraparietal haustoria-like structures were commonly observed. These were peglike protrusions of the fungal cell wall that penetrated into an adjacent algal cell wall (Figs. 33-38). The protrusions generally appeared in section as solid wall material (Fig. 33), with no more than a slight corresponding protrusion of the fungal protoplast at the base (Fig. 34), but without any central strand of protoplasm detectable within. The depth of penetration and thinning of the algal wall varied; in a number of cases, the algal wall was nearly traversed, but in no instance were fungal structures seen to enter the algal cell lumen. Frequently, a substantial delamination of the algal cell wall was evident around the haustorium-like structure, with fungal wall material penetrating between the separated layers of algal wall (Figs. 35-38). Conversely, the downward growth of the algal filaments involved a reciprocal penetration through the fungal tissue. The terminal cells of the algal filaments typically became narrow and sinuous apically as they forced their way through the wall material between fungal cells (Fig. 39). These intrusions of the algal filaments could penetrate deeply into the fungal cell wall, which often was substantially thinner at such contact points (Figs. 40-42). In some cases, a proliferation of cytoplasmic membranes was notable in the fungal protoplast adjacent to these contacts (Fig. 42).

\section{DISCUSSION}

The Phaeophyceae, to which Petroderma belongs, are included among the ochrophyte algae, a group characterized by heterokontic, straminipilous flagella (Graham and Wilcox, 2000). The ochrophytes also include the Xanthophyceae, of which one member (Heterococcus caespitosus) has also been reported as phycobiont in three species of Verrucaria lichens (Tschermak, 1941; Zeitler, 1954; Parra and Redón, 1977). Together with certain heterotrophic organisms such as the oomycetes, the ochrophyte algae may be placed within a distinct kingdom denominated Chromista (Cavalier-Smith, 1998) or Straminipila (Dick, 2001). Petroderma and Heterococcus are thus very different phylogenetically from both the chlorophyte and cyanophyte algae that serve as phycobionts in all other known lichen associations.

Despite the distinctive nature of the phycobiont, Verrucaria tavaresiae and Petroderma maculiforme form a lichen thallus with an organization comparable to that of many other crustose lichens. Within a cellular tissue formed by the fungus, $\mathrm{Pe}$ - 


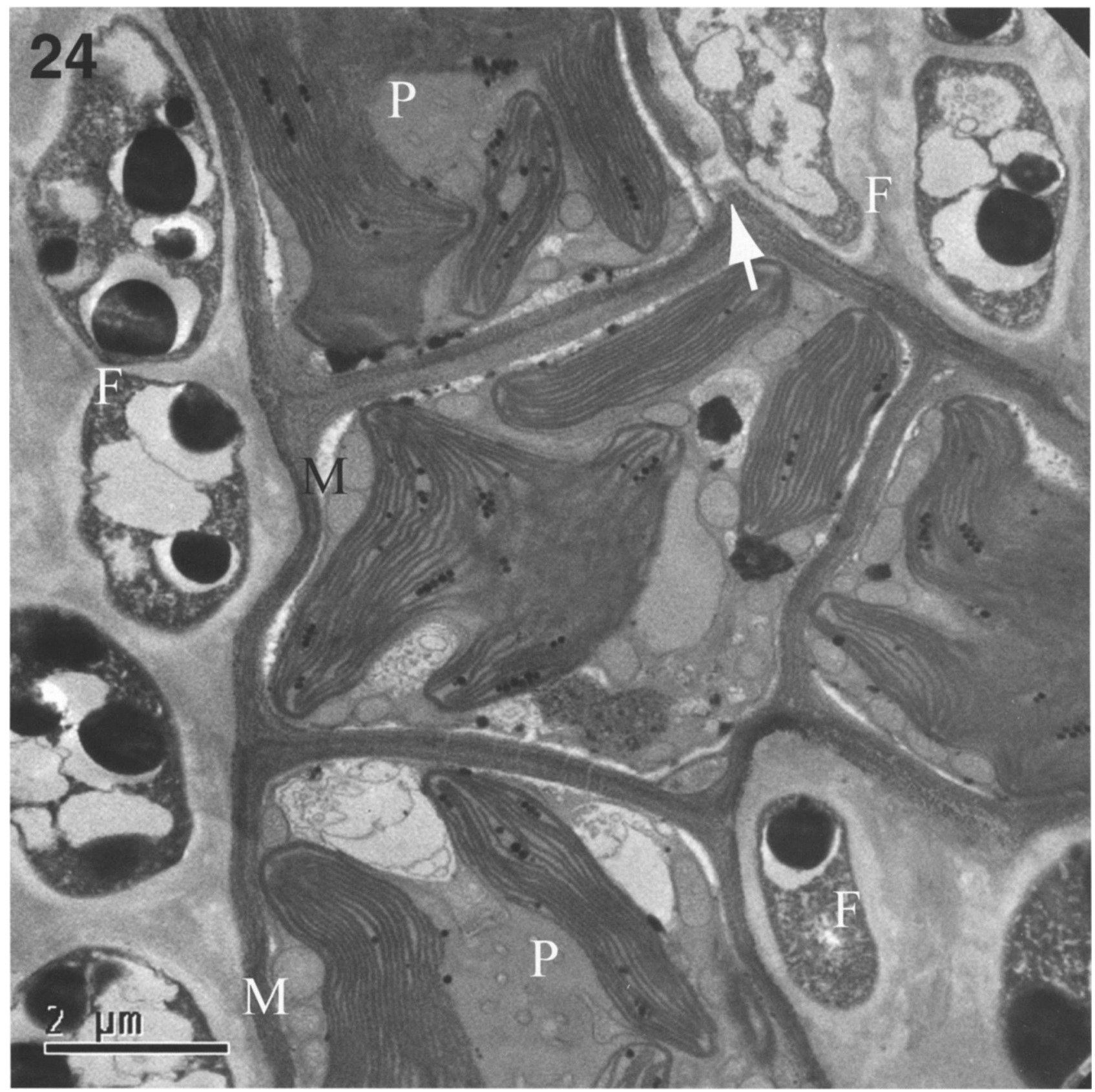

Fig. 24. Ultrastructure of the Verrucaria tavaresiae-Petroderma maculiforme thallus. Fungal cells (F), with large electron-dense globules, surround a branching algal filament. The algal cells contain chloroplasts with lobes encircling a pyrenoid $(\mathrm{P})$ and numerous mitochondria $(\mathrm{M})$. The branching algal cell at the center appears to contain more than one chloroplast. Fungal penetration of algal wall (arrow) is shown at greater magnification in Fig. 33 . Scale bar $=2$ $\mu \mathrm{m}$.

troderma is transformed into a discrete layer of separate, downward-growing filaments. Thus, the growth properties of both filamentous fungus and multicellular alga are profoundly altered in symbiosis. The cytological characteristics of the mycobiont are quite similar to those described in other ascomycete lichens. Fungal cell walls are "gelatinized" or confluent in an apparent matrix, and their protoplasts show a conspicuous vacuolar system with osmiophilic contents reminiscent of those reported in other lichens (Boissière, 1979, 1982). The fungal cytoplasm contains concentric bodies, a feature ob- served in most lichenized ascomycetes that have been studied ultrastructurally. The significance of these structures is still unclear, but their occurrence seems to be correlated with fungi subject to drought stresses (Honegger, 1993). Their presence in $V$. tavaresiae, which colonizes an intertidal habitat, is certainly compatible with this pattern. The diurnal alternation between full immersion and exposure probably causes considerable mechanical stress on the thallus tissue. Cracking of the thallus upon drying often occurs along the pigmented markings of the upper thallus layers, as previously reported in an- 

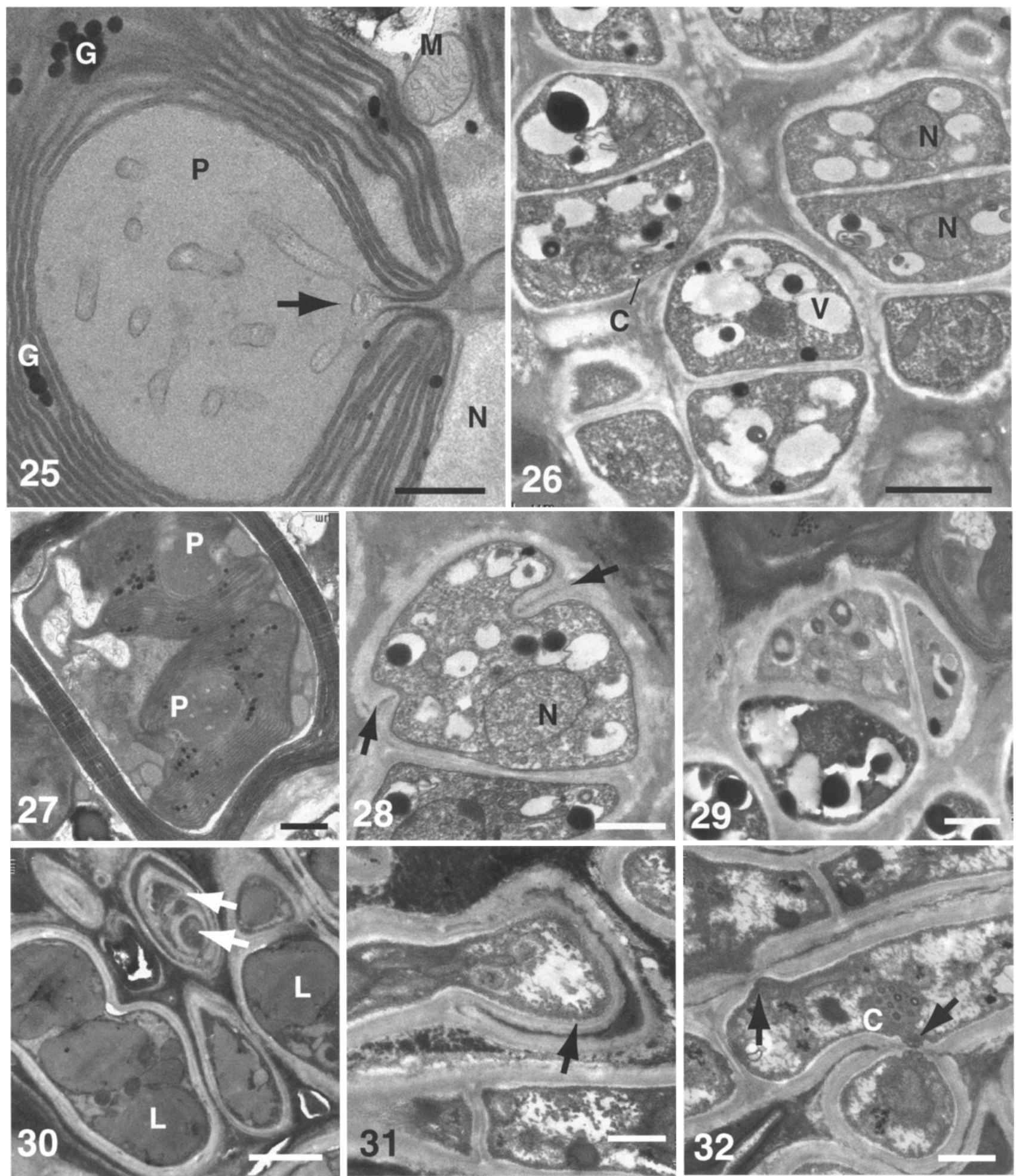

Figs. 25-32. Ultrastructure of the Verrucaria tavaresiae-Petroderma maculiforme thallus. C, concentric bodies; G, plastoglobuli; L, lipid globules; N, nucleus; P, pyrenoid; V, vacuole. 25. Central pyrenoid enfolded by lobes of chloroplast. Invagination of chloroplast membrane (horizontal arrow) gives rise to branching membranous tubules that traverse the pyrenoid. The nucleus and mitochondria lie close by. Plastoglobuli occur within dilations of stroma between lamellae and are generally absent from the pyrenoid. Scale bar $=0.5 \mu \mathrm{m}$. 26. Fungal cells dividing periclinally (new septa approximately parallel to thallus surface) immediately below algal layer. Electron-dense globules associated with vacuoles are relatively reduced in size (compare to Fig. 24$)$. Scale bar $=2$ $\mu \mathrm{m}$. 27. Algal filament cell containing two chloroplasts, each with a central pyrenoid (P). Plasmodesmata traverse filament crosswalls. Scale bar $=1 \mu \mathrm{m}$. 28 . Fungal cell forming oblique, asymmetrical septum (arrows). Scale bar $=1 \mu \mathrm{m}$. 29. Fungal cell divisions in perpendicular planes, directly below branching algal filament. Scale bar $=1 \mu \mathrm{m}$. 30. Medulla: fungal cells filled with large lipid globules not associated with vacuoles. Arrows indicate intrahyphal hyphae. Scale $\mathrm{bar}=2 \mu \mathrm{m}$. 31. Medulla: intrahyphal hypha (arrow) invading adjacent compartment across septum. Scale bar $=1 \mu \mathrm{m}$. 32. Medulla: fungal cells showing anastomoses between adjacent lateral walls (arrows). Scale bar $=1 \mu \mathrm{m}$. 

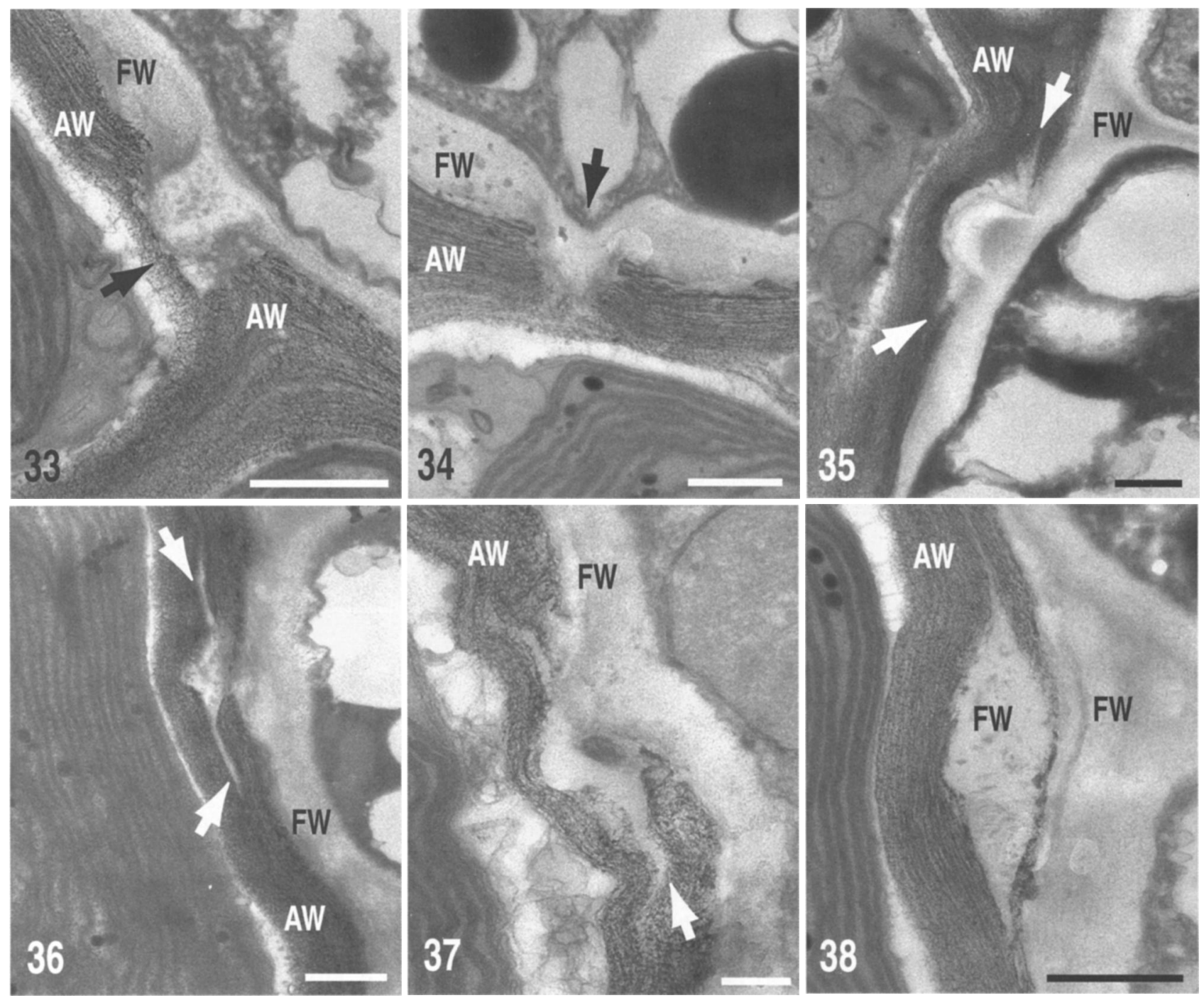

Figs. 33-38. Ultrastructure of the Verrucaria tavaresiae-Petroderma maculiforme thallus: fungal penetration into algal wall. FW, fungal wall; AW, algal wall. 33. Detail of penetration peg shown in Fig. 24. Arrow indicates unpenetrated layers of algal wall remaining against fungal protrusion. Scale bar $=0.5$ $\mu \mathrm{m}$. 34. Penetration peg with slight protrusion of fungal protoplast at base (arrow). Scale bar $=0.5 \mu \mathrm{m}$. 35. Penetration peg delaminating algal cell wall laterally (arrows). Scale bar $=0.5 \mu \mathrm{m}$. 36. Peg with fungal wall material penetrating broadly between algal cell wall layers (arrows). Scale bar $=0.5 \mu \mathrm{m}$. 37 . Lateral portion of penetration peg inserted between algal cell wall layers (arrow). Scale bar $=0.2 \mu \mathrm{m}$. 38. Non-median section of penetration peg showing fungal wall material intercalated between algal wall layers. Scale bar $=0.5 \mu \mathrm{m}$.

other maritime Verrucaria species, V. degelii (Santesson, 1939).

The cellular contacts between the symbionts have distinctive structural features. While so-called intraparietal haustoria are typical of many lichens, the observed separation of algal wall layers and insertion of fungal wall material between them does not appear to have been reported previously. The reciprocal penetration by intrusive growth of the algal filaments into the fungal walls is another striking feature of this symbiosis. These elaborate interpenetrations between symbionts might provide increased integration of cells within a tissue that is subject not only to the mechanical stresses of hydric extremes, but also to the markedly divergent cellular growth patterns of its two biological components.

Inferred model of thallus growth-Because the crustose thallus of $V$. tavaresiae is intimately attached to the substra- tum, radial growth must take place at the thallus margin, where stages in thallus development are observable. The periclinally oriented filaments of the phycobiont present at the thallus margin are interpenetrated by fungal cells and reorganized into short, separate, anticlinally oriented filaments. Several observations indicate that the growth of these anticlinal algal filaments is primarily downward into the fungal tissue: (1) branches of the lichenized algal filaments are usually oriented downward; (2) the lowermost cells of the filaments grow intrusively between the cells of the fungal tissue below; and (3) the uppermost cells of the algal filaments are often moribund and physically eroded, as are those of adjacent fungal cells. Compared to the erect filaments of the free-living Petroderma, the lichenized algal filaments appear to have the reverse polarity of growth. The growth of the phycobiont downward into the fungal tissue permits the algal layer to maintain its position among the periclinally dividing fungal cells while regenerating 

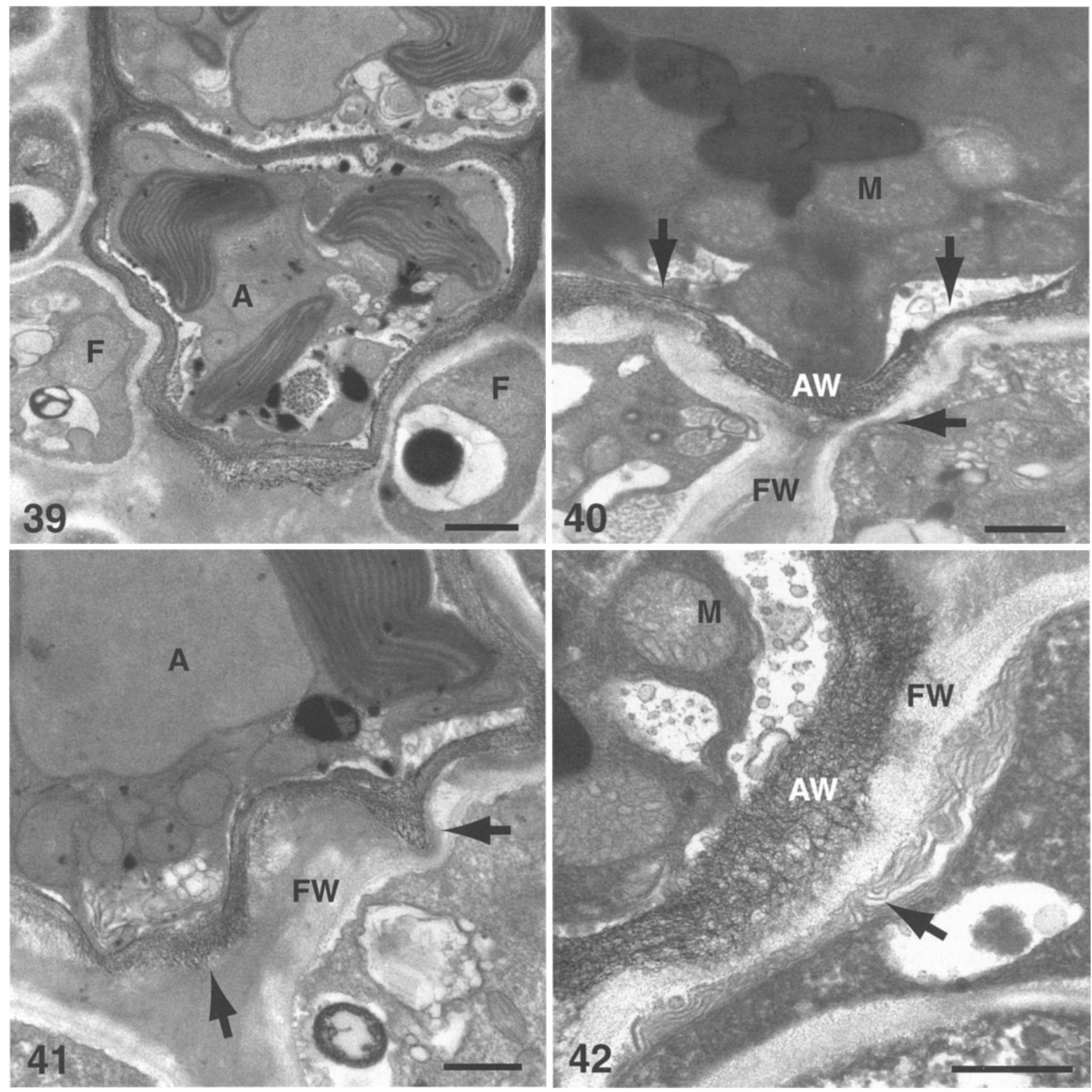

Figs. 39-42. Ultrastructure of the Verrucaria tavaresiae-Petroderma maculiforme symbiosis. Intrusive growth of algal filaments into underlying fungal tissue. A, alga; AW, algal wall; F, fungus; FW, fungal wall; M, mitochondria. 39. Tip of algal filament growing through wall material between fungal cells. Scale bar $=1 \mu \mathrm{m}$. 40. Tip of algal filament pushing downward into adjacent fungal cells. Fungal wall is markedly thinner (horizontal arrow) where alga has penetrated. At nearby points, protrusions of the fungal wall penetrate reciprocally into the algal cell wall (vertical arrows). Scale bar $=0.5 \mu \mathrm{m}$. $\mathbf{4 1}$. Intrusive projections of algal filament tip cell penetrating into fungal cell wall (arrows). Scale bar $=0.5 \mu \mathrm{m}$. 42. Penetration of alga into fungal cell wall, with membrane proliferation in adjacent fungal protoplast (arrows). Scale bar $=0.5 \mu \mathrm{m}$.

algal cells to replace those sloughed off at the upper surface of the thallus.

The arrangement of fungal cells in files, with mainly periclinal crosswalls visible, indicates considerable production of fungal tissue perpendicular to the surface of the thallus. These cell divisions appear to be most concentrated within a region comprising the lower algal layer and upper subalgal layer. Several observations support this interpretation: (1) Fungal cells in this region tend to be smaller, thinner-walled, and arranged in anticlinal files with mostly periclinal crosswalls evident. (2) The cytoplasm of the cells in this zone stain most densely with aniline blue (Figs. 9, 19), suggesting intense metabolic activity. (3) The highly electron-dense globules associated with vacuoles in the algal and subalgal layers often appear markedly smaller in the lower algal and upper subalgal region, suggesting mobilization of resources by these cells for growth processes (Figs. 10-11,26). The subsurface cell divisions may provide for the renewal of fungal tissue removed by abrasion 
of the surface through wave action and the scouring effect of suspended particles, analogous to the basal replacement of grazed leaf tissue by intercalary meristems in grasses. Herbivory by intertidal organisms, an important factor in the ecology of many intertidal plants, may also contribute significantly to removal of surface tissues in Verrucaria tavaresiae (Fig. 2).

Fungal-algal contacts-Previous workers described symbiont interactions in other species of Verrucaria. With light microscopy, Tschermak (1941) observed tiny intraparietal haustoria in Verrucaria nigrescens Pers. and related Dermatocarpon species, but reported an absence of penetrating structures in the lichen formed by Verrucaria elaeomelaena $(=V$. funckii according to Tschermak-Woess, 1988) and its thinwalled xanthophycean phycobiont Heterococcus. Tschermak (1941: fig. 7n, p) also discerned pairs of closely spaced penetrating structures in $V$. nigrescens; their resolution must have approached the limits of the light microscope. Such closely adjacent penetrations were not observed in the present study of $V$. tavaresiae, although they were apparent in electron micrographs of other Verrucaria species examined by Galun et al. (1973: fig. 2) and Kushnir and Galun (1977: fig. 5). Those authors claimed that in haustorial interactions of pyrenocarpous lichens such as Dermatocarpon and Verrucaria, the fungal cell wall as well as the algal wall disintegrate, and a naked fungal protoplast emerges toward the algal cell. This conclusion appeared to be based on micrographs in which an electron-transparent area exterior to the fungal protoplast was interpreted as a "space" (fig. 4 in Galun et al., 1971; figs. 2-3 in Kushnir and Galun, 1977). However, the electron-transparent areas in question may actually correspond to the fungal cell wall. In the present study, no dissolution of fungal wall was observed where the algal cell wall was penetrated, although the fungal wall was thinner where intrusively growing algal filaments pushed downward against the fungal cells below them (Figs. 40-42). The deeply penetrating, intracellular fungal haustoria seen within the algal cell lumen in a number of pyrenolichens growing on bark (Matthews et al., 1989) and leaves (Chapman, 1976) were not observed in $V$. tavaresiae.

In general, the structurally primitive crustose thalli with unstratified organization tend to have deeply penetrating intracellular haustoria, while the more structurally advanced crustose, foliose, and fruticose lichens have either non-penetrative contacts between symbionts or intraparietal penetrations that do not enter the algal cell lumina (Tschermak, 1941; Plessl, 1963; Honegger, 1986). Verrucaria tavaresiae appears consistent with this general pattern. Within its stratified, highly organized thallus, penetration of the phycobiont is limited to intraparietal protrusions of the mycobiont wall. In certain lichens, the type of symbiont contact may also be influenced by structural features of particular algal symbionts. For example, the lack of wall penetration in lichens containing the phycobiont Coccomyxa (Tschermak, 1941; Peveling and Galun, 1976) might be explained by the presence of degradation-resistant polymers in the algal cell wall (Brunner and Honegger, 1985; Honegger, 1988). In V. tavaresiae, the delamination of the algal wall near points of fungal penetration might be at least partly attributable to structural characteristics peculiar to the phaeophyte cell wall.

Although lichen haustoria have been repeatedly studied, their function and significance are still not fully understood. While the term haustorium suggests a specialized absorptive structure, there is no evidence that lichen haustoria indeed play such a role. Neither autoradiographic studies with labeled carbohydrate (Jacobs and Ahmadjian, 1971; Hessler and Peveling, 1978) nor calculations of carbohydrate movement between symbionts (Collins and Farrar, 1978) have indicated any special relevance of lichen haustoria in the transfer of nutrients between symbionts. Clearly, the simple intraparietal haustoria present in many lichen thalli do not substantially increase the surface area of contact between the symbiont protoplasts, as do the branching, intracellular haustoria typical of plant parasites and endomycorrhizae. In $V$. tavaresiae, the fungal penetration pegs are protruding wall material usually without fungal protoplasm, further undermining speculation that these structures might facilitate transfer of materials. Their function may well be more structural than nutritional. The laterally penetrating flanges lock the fungal penetration pegs within the algal wall, impeding separation of the contacting symbiont cell surfaces. The converse penetration of algal filaments into the fungal cell wall may further help bind the symbiont cells together. These reciprocal penetrations may thus facilitate the coherence and integration of unlike cellular elements, much as the anastomoses that bind like cells of adjacent filaments (Fig. 32) play an important role in the construction of a pseudoparenchyma (Poelt, 1986). This may be of particular significance in lichen tissues subject daily to mechanical stresses of extreme hydration and dehydration. In growth zones of lichens containing the unicellular phycobiont Trebouxia, a related role in integrating or coordinating symbiont growth in morphogenesis has been attributed to the penetrative hyphae that separate and shift dividing algal cells (Greenhalgh and Anglesea, 1979; Honegger, 1987). Thus, the originally absorptive, nutritional function of intracellular haustoria in primitive lichens may have evolved into a more structural/mechanical role, allowing dividing algal cells to be more closely coordinated or shifted with fungal growth and thereby permitting the construction of more highly organized lichen thalli.

Ecological and reproductive considerations-Although reports of the diminutive and easily overlooked Petroderma are scanty, the microhabitat preferences of the independent alga appear to be distinct from those of the lichenized form. Freeliving $P$. maculiforme is not very tolerant of strong wave action nor of desiccation (Wilce et al., 1970). It occupies the lowermost regions of the intertidal zone, except where protected moist crevices permit it to colonize higher, and frequently occurs submerged in tidal pools (Edelstein and McLachlan, 1969; Fletcher, 1987). In San Francisco Bay, freeliving Petroderma was most readily found on discarded plastic among rocks and sand exposed only at very low tide at the calmer East Bay shore. Lichen symbiosis with Verrucaria tavaresiae therefore appears to extend the alga's range into more exposed microhabitats subject to vigorous wave action and more extreme desiccation. On the other hand, the lichenized Petroderma populations have not been observed to form reproductive structures. Nor does the lichen bear any recognizable type of vegetative propagule that includes the algal symbiont. Verrucaria tavaresiae appears to reproduce via ascospores, which after dispersal and germination must relichenize Petroderma germlings or zoospores originating from free-living algal thalli. Established Petroderma thalli probably do not become lichenized, as the lichen does not appear to thrive where the free-living alga does.

This situation appears to contrast with that of the lichen Strigula, which can colonize leaves bearing the reproductively 
mature, free-living thalli of its phycobiont Cephaleuros (see fig. 4 in Sanders, 2001). According to Ward (1884), the germinating spores of Strigula complanata $(=S$. orbicularis $)$ consume rather than lichenize very young Cephaleuros thalli and can only form stable lichen symbioses when algal thalli in more advanced stages of development are contacted. The comparison is of interest because Cephaleuros (Trentepohliaceae) is perhaps the only known lichen phycobiont equivalent in structural complexity to Petroderma.

The complete suppression of algal reproduction and dispersal after lichenization would seem unlikely, because occasional phycobiont "escape" and sexual recombination are necessary for symbiotic coevolution. The level of thallus organization and lack of apparent parasitism of the algal cells indicate that this lichen symbiosis is indeed stable and highly coevolved. It is possible that Petroderma might regenerate and reproduce free-living from abraded lichen fragments in nature as it readily does in culture (Peters and Moe, 2001) or indeed produce zooangia on lichenized filaments under certain conditions or at certain times of the year. However, a molecular comparison of lichenized Petroderma from California and free-living Petroderma from the type locality in the North Sea showed identical nuclear ribosomal ITS1 sequences; this highly variable gene typically differs between species and even populations in brown algae (Peters and Moe, 2001). The suggestion of genetic uniformity between these widely separated populations is surprising, and it will be interesting to see if comparison of other informative genes gives similar results.

Lichens vs. mycophycobioses-Various authors have differed slightly in the characteristics they emphasize as definitive of a lichen symbiosis, as distinct from other types of fungalalgal symbioses. Hawksworth (1988) stressed that the fungal component is the exhabitant, enclosing the algal symbiont, while Jahns (1988) emphasized the formation of a distinctive thallus by the mycobiont. The Verrucaria tavaresiae-Petroderma maculiforme symbiosis clearly fits these definitions, distinguishing it from other known fungus-phaeophyte symbioses. Yet one might question whether the distinction of lichens from mycophycobioses is always made consistently and indeed whether this distinction is always biologically meaningful. For example, the Collemataceae include certain species of fungi with hyphae that simply penetrate the sheath material of Nostoc without forming any vegetative tissues or external cortex. It is hardly clear that these fungi should be considered exhabitants, nor that their thalli represent substantial morphological transformation when compared to macroscopic, freeliving aggregates of Nostoc. Nonetheless, the status of these associations as lichens is not questioned, while those formed by Mycophycias with seaweeds have been treated distinctly. Conversely, the glomalean fungus Geosiphon pyriforme alters its hyphal morphology to produce bladder-like swellings in the presence of its algal symbiont, and the fungus is clearly the exhabitant (the alga is actually enclosed within the fungal cell lumina; Schüßler and Kluge, 2001), yet this association is not considered to be a lichen. In practice, the boundaries we give to the lichen concept may actually be influenced by the perceived biosystematic affiliations of the fungi involved. If Geosiphon pyriforme or Mycophycias ascophylli were closely related to other fungal taxa known to form typical lichen thalli, it is likely that we would consider them also to be lichens and modify our definitions accordingly. The same would surely apply to the Turgidosculum complicatulum-Prasiola crispa association, whose status as a lichen (Lamb, 1948) may still face some lingering doubts (Lud et al., 2001). In the case of Mycophycias and its seaweed hosts, a close ecological correspondence with lichen symbioses might be implied by obligatory co-occurrence, as well as by data suggesting improved algal host growth (Garbary and MacDonald, 1995) and tolerance of desiccation (Garbary and London, 1995). In this regard it is worth mentioning that recent taxonomic placement of the genus Mycophycias in the Verrucariales (Kohlmeyer and Volkmann-Kohlmeyer, 1998) suggests the possibility of a closer phylogenetic relationship with lichenized taxa such as Verrucaria, a hypothesis worthy of further investigation. However, the structural criteria that at present figure prominently in our definition of a lichen clearly place Verrucaria tavaresiae among the lichens while excluding Mycophycias ascophylli.

\section{LITERATURE CITED}

Asensi, A., R. Delépine, and G. Guglielmi. 1977. Nouvelles Observations sur l'ultrastructure du plastidome des Phéophycées. Société Phycologique de France, Bulletin 22: 192-205.

Boissière, M.-C. 1979. Cytologie du Peltigera canina (L.) Willd. en microscopie électronique: le mycobionte a l'état végétatif. Révue de $M y$ cologie 43: 1-49, Pls. I-XX.

BoISSIÈre, M.-C. 1982. Cytochemical ultrastructure of Peltigera canina: some features related to its symbiosis. Lichenologist 14: 1-27.

BRunNER, U., AND R. HoNEGGER. 1985. Chemical and ultrastructural studies on the distribution of sporopolleninlike biopolymers in six genera of lichen phycobionts. Canadian Journal of Botany 63: 2221-2230.

CAVAlier-Smith, T. 1998. A revised six-kingdom system of life. Biological Review 73: 203-266.

Chapman, R. L. 1976. Ultrastructural investigation on the foliicolous pyrenocarpous lichen Strigula elegans (Fée) Müll. Arg. Phycologia 15: 191196.

COllins, C. R., AND J. F. FARRAR. 1978. Structural resistances to mass transfer in the lichen Xanthoria parietina. New Phytologist 81: 71-83.

Dick, M. W. 2001. Straminipilous fungi. Kluwer Academic, Dordrecht, Netherlands.

Edelstein, T., And J. MCLachlan. 1969. Petroderma maculiforme on the coast of Nova Scotia. Canadian Journal of Botany 47: 561-563.

Fletcher, R. L. 1987. Seaweeds of the British Isles, vol. 3, Fucophyceae (Phaeophyceae), part 1. British Museum (Natural History), London, UK.

Galun, M., E. Kushnir, L. Behr, AND Y. Ben-Shaul. 1973. Ultrastructural investigation on the alga-fungus relation in pyrenocarpous lichen species. Protoplasma 78: 187-193.

Galun, M., N. Paran, AND Y. Ben-Shaul. 1971. Electron microscopic study of the lichen Dermatocarpon hepaticum (Ach.) Th. Fr. Protoplasma 73: 457-468.

GARBARY, D. J., AND J. F. London. 1995. The Ascophyllum/Polysiphonial Mycosphaerella symbiosis. V. Fungal infection protects $A$. nodosum from desiccation. Botanica Marina 38: 529-533.

Garbary, D. J., And K. A. MacDonald. 1995. The Ascophyllum/Polysiphonia/Mycosphaerella symbiosis. IV. Mutualism in the Ascophyllum/ Mycosphaerella interaction. Botanica Marina 38: 221-225.

Graham, L. E., and L. W. Wilcox. 2000. Algae. Prentice-Hall, Upper Saddle River, New Jersey, USA.

Greenhalgh, G. N., AND D. Anglesea. 1979. The distribution of algal cells in lichen thalli. Lichenologist 11: 283-292.

HAWKSWORTH, D. L. 1988. The variety of fungal-algal symbioses, their evolutionary significance, and the nature of lichens. Botanical Journal of the Linnean Society 96: 3-20.

Hessler, R., AND E. Peveling. 1978. Die Lokalisation von ${ }^{14} \mathrm{C}$-Assimilaten in Flechtenthalli von Cladonia cristatella Floerke und Hypogymnia physodes (L.) Ach. Zeitschrift für Pflanzenphysiologie 86: 287-302.

Honegger, R. 1986. Ultrastructural studies in lichens. I. Haustorial types and their frequencies in a range of lichens with trebouxioid photobionts. New Phytologist 103: 785-795.

HoNEGGER, R. 1987. Questions about pattern formation in the algal layer of lichens with stratified (heteromerous) thalli. Bibliotheca Lichenologica 25: $59-71$.

HonEGgER, R. 1988. The functional morphology of cell-to-cell interacions 
in lichens. In S. Scannerini, D. Smith, P. Bonfante-Fasolo, and V. Gianinazzi-Pearson [eds.], Cell-to-cell signals in plant, animal and microbial symbiosis, 39-53. Springer-Verlag, Berlin, Germany.

HoNEGGER, R. 1993. Developmental biology of lichens. New Phytologist 125: 659-677.

JaCOBS, J. B., AND V. Ahmadjian. 1971. The ultrastructure of lichens. IV. Movement of carbon products from alga to fungus as demonstrated by high resolution radioautography. New Phytologist 70: 47-50, Pls. 1-2.

JaHNS, H. M. 1988. The lichen thallus. In M. Galun [ed.], CRC handbook of lichenology, vol. 1, 95-143. CRC Press, Boca Raton, Florida, USA.

KOHLMEYER, J., AND E. KOHLMEYER. 1972. Is Ascophyllum nodosum lichenized? Botanica Marina 15: 109-112.

KOHLMEYER, J., AND B. VOLKMANN-KoHLMEYER. 1998. Mycophycias, a new genus for the mycobionts of Apophlaea, Ascophyllum, and Pelvetia. Systema Ascomycetum 16: 1-7.

KuSHNiR, E., AND M. GaLun. 1977. The fungus-alga association in endolithic lichens. Lichenologist 9: 123-130.

LAMB, I. M. 1948. Antarctic pyrenocarp lichens. Discovery Reports 25: 130.

Lud, D., A. H. L. Huiskes, AND S. OTt. 2001. Morphological evidence for the symbiotic character of Turgidosculum complicatulum Kohlm. \& Kohlm. (=Mastodia tesselata Hook.f. \& Harvey). Symbiosis 31: 141151.

MatThews, S. W., S. C. TUCKER, AND R. L. ChAPMAN. 1989. Ultrastructural features of mycobionts and trentepohliaceous phycobionts in selected subtropical crustose lichens. Botanical Gazette 150: 417-438.

MOE, R. 1997. Verrucaria tavaresiae sp. nov., a marine lichen with a brown algal photobiont. Bulletin of the California Lichen Society 4: 7-11.

ParRa, O. O., AND J. Redón. 1977. Aislamiento de Heterococcus caespitosus Vischer ficobionte de Verrucaria maura Wahlenb. Boletín de la Sociedad Biológica de Concepción 51: 219-224.

Peters, A., And R. Moe. 2001. DNA sequences confirm that Petroderma maculiforme (Phaeophyceae) is the brown algal phycobiont of the marine lichen Verrucaria tavaresiae (Verrucariales, Ascomycotina) from central California. Bulletin of the California Lichen Society 8: 41-43.
Peveling. E., And M. Galun. 1976. Electron-microscopical studies on the phycobiont Coccomyxa Schmidle. New Phytologist 77: 713-718.

PlessL, A. 1963. Über die Beziehungen von Haustorientypus und Organizationshöhe bei Flechten. Österreichische Botanische Zeitschrift 110: 194-269.

POELT. J. 1986. Morphologie der Flechten: Fortschritte und Probleme. Berichte der deutschen botanischen Gesellschaft 99: S. 3-29.

SANDERS, W. B. 2001. Lichens: the interface between mycology and plant morphology. Bioscience 51: 1025-1035.

SANTESSON, R. 1939. Amphibious pyrenolichens I. Arkiv för Botanik 29A (10): 1-67.

SChÜBler, A., AND M. Kluge. 2001. Geosiphon pyriforme, an endocytosymbiosis between fungus and cyanobacteria, and its meaning as a model system for arbuscular mycorrhizal research. In B. Hock [ed.], The mycota, vol. IX. Fungal associations, 151-161. Springer-Verlag, New York, New York, USA.

TsCHERMAK, E. 1941. Untersuchungen über die Beziehungen von Pilz und Alge im Flechtenthallus. Österreichische Botanische Zeitschrift 90: 233307.

TsChermak-Woess, E. 1988. The algal partner. In M. Galun [ed.], CRC handbook of lichenology, vol. I, 39-92. CRC Press, Boca Raton, Florida, USA.

TUCKER, S. C. 1999. Report on Von Reis lichens from the herbarium of California Polytechnic University, San Luis Obisbo. Bulletin of the California Lichen Society 6: 3-7.

WARD. H. M. 1884. On the structure, development and life history of a tropical epiphyllous lichen (Strigula complanata Fée). Transactions of the Linnean Society of London, Botany 2: 87-119.

Wilce. R. T., E. E. Webber, AND J. R. SEARS. 1970. Petroderma and Porterinema in the New World. Marine Biology 5: 119-135.

WyNNE, M. J. 1969. Life history and systematic studies of some Pacific North American Phaeophyceae (brown algae). University of California Publications in Botany 50: 1-88.

ZeITLER, I. 1954. Untersuchungen über die Morphologie, Entwicklungsgeschichte und Systematik von Flechtengonidien. Österreichische Botanische Zeitschrift 101: 453-487. 